YEARBOOK of ANTITRUST and REGULATORY STUDIES www.yars.wz.uw.edu.pl
Peer-reviewed scientific periodical, focusing on legal and economic issues of antitrust and regulation. Creative Commons Attribution-No Derivative Works 3.0 Poland License.

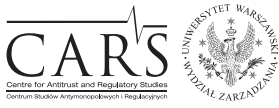

Centre for Antitrust and Regulatory Studies, University of Warsaw, Faculty of Management www.cars.wZ.uw.edu.pl

\title{
2015 Amendments to the Aviation Law Act
}

\author{
by
}

\section{Anna Konert* and Piotr Kasprzyk ${ }^{* *}$}

\section{CONTENTS $^{* * *}$}

I. Introduction

II. Air traffic flow management

III. Using military airports for civil air transport

IV. Forthcoming amendment of the Aviation Law Act

Key words: air traffic flow management; aviation law; civil transport; military airports.

JEL: L93

\section{Introduction}

In 2015, the Polish Parliament passed two amendments to the Act of 3 July 2002 - Aviation Law ${ }^{1}$. The first of the Amendments adjusted Polish law to EU rules on air traffic flow management. The second made it possible to use military airports to perform civil aviation operations, especially flights conducted for the Polish Armed Forces. 2015 saw also the start of legislative works on a more comprehensive amendment of the Aviation Law Act. The latter are to adapt national laws to rapidly changing EU legislation, in particular in the field of aviation safety.

* Prof. dr hab. Anna Konert - vice-dean of Faculty of Law and Administration, Lazarski University (Warsaw, Poland); a director of Institute of Air Transport; a.konert@lazarski.edu.pl

** Dr Piotr Kasprzyk - a legal adviser specializing in aviation law.

*** Article received: 23 March 2016; accepted: 30 March 2016.

1 Consolidated text: Journal of Laws 2013 No. 1393 as amended. 


\section{Air traffic flow management}

Commission Regulation (EU) No. 255/2010 of 25 March 2010 laying down common rules on air traffic flow management ${ }^{2}$ (hereafter, Regulation 255/2010) introduced a number of measures regarding Air Traffic Flow Management (hereafter, ATFM). They were meant to optimize available airspace capacity and enhance ATFM processes. Regulation 255/2010 was based on one of the four basic Regulations ${ }^{3}$ establishing the framework of the so-called Single European Sky package. According to Regulation 255/2010, ATFM measures should be based on principles laid down by the International Civil Aviation Organization. Moreover, all parties to the ATFM system should adhere to rules that ensure that air traffic control capacity is used safely and to the maximum extent possible.

The ATFM measures should prevent excessive air traffic demand, compared with declared Air Traffic Control (hereafter, ATC) capacity of sectors and airports. They should use the capacity of the European Air Traffic Management Network (hereafter, EATMN) to the maximum extent possible, in order to optimize the efficiency of the EATMN. They are meant to minimize adverse effects on operators, optimize the EATMN capacity made available through the development and application of capacity enhancing measures by ATS units, as well as support the management of critical events. Furthermore, according to Regulation 255/2010, operators (air carriers and other air users) need to respect the allocated airport slots and filed flight plans ${ }^{4}$.

Article 15 of Regulation 255/2010 imposed an obligation upon EU Member States to create the framework for the imposition of penalties for infringements of the provisions of this Regulation as well as a duty to take all measures necessary to ensure that the penalties are in fact implemented. The penalties provided for must be effective, proportionate and dissuasive. The introduction of penalties is to transpose the requirements of Regulation 255/2010 as the defined practices reduce the effectiveness of air traffic management. In particular, problems exist with relation to the use of multiple flight plans and violations of allocated airport slots.

2 OJ 2010 L 80/10.

3 Regulation (EC) No. 551/2004 of the European Parliament and of the Council of 10 March 2004 on the organization and use of the airspace in the Single European Sky (OJ L 96/20).

${ }^{4}$ See Article 7 ('Each intended flight shall be covered by a single flight plan. The filed flight plan shall correctly reflect the intended flight profile. All relevant ATFM measures and changes thereto shall be incorporated into the planned flight operation and communicated to the pilot.') 
Poland was under the obligation to implement Regulation 255/2010 by 2011 yet it has failed to do so. In September 2014, the European Commission called upon Poland to adopt the necessary legislation establishing penalties for infringements of Regulation 255/2010, threatening Poland with a referral to the Court of Justice. These steps are in line with the Commission's power to take legal action against a Member State that is not respecting its obligations under EU law'. After receiving a 'Reasoned Opinion' from the Commission, the Polish government developed a draft of the necessary amendments to its Aviation Law ${ }^{6}$. These legislative works resulted in the enactment of the Law of 5 August 2015 Amending the Act - Aviation Law?

The essence of the amendment is to clarify some EU law solutions on ATFM at the national level and to introduce so-called 'administrative penalties' into the Aviation Law Act (Section XIA of the Act) as sanctions for breaches of the requirements of Regulation 255/2010.

A breach of Regulation 255/2010 (Article 209c) has been specifically named in the Annex to the Aviation Law Act and associated with financial penalties. These penalties may be imposed by the President of Civil Aviation Authority (hereafter, CAA) in relation to those entities that infringe certain of their responsibilities associated with ATFM, namely: the Air Traffic Service (hereafter, ATS), acting as ATM bodies ${ }^{8}$, slot coordinators and airport managing bodies.

The Amendment introduced a catalog of administrative penalties that can be imposed by a decision of the President of the CAA as a result of a finding that a breach had occurred of the obligations imposed by Regulation 255/2010 as far as, among others, compliance with: flight plans, the allocation of time slots, or procedures for handling critical events.

However, it was not explained in the course of the legislative works why some of the fines are set in the range 'from ...to' while others have a directly specified amount. The Amendment introduced the general principle whereby penalties referred to in the Aviation Law Act cannot be included in the costs related to the tasks financed from coordination fees, airport fees and navigation fees. Otherwise, the fined entity could get compensation for the fine by increasing costs, which are the basis for determining the fees charged.

5 http://ec.europa.eu/polska/news/140925_przestrzen_pl.htm

${ }^{6}$ Form 3663, draft was sent to the Parliament in July 2015.

7 Journal of Laws 2015, item 1586.

8 In Poland, this is the Polish Air Navigation Services Agency, managing the flow of air traffic on the basis of Article 3 of the Act of 8 December 2006 on the Polish Air Navigation Services Agency (Journal of Laws 2006 No. 249, item 1829 as amended.). 


\section{Using military airports for civil air transport}

The second Amendment Act to the Aviation Law passed in 2015 is the result of an earlier document stating the assumptions behind the Daft Act prepared by the Ministry of Defence, which pointed out the growing demand of the Armed Forces for civil air transport.

The Draft explained that Polish aviation law applicable at that time separates civil aviation from military aviation solely on the basis of which registry has a given aircraft been listed in - the civil or the military registry. At the same time, the law stipulated that civil aircrafts could, in principle, operate only from civil airports. Consequently, it was not possible to operate civil aircraft flights from, or to military airport even if the aircraft was chartered by the military to transport soldiers or military equipment. Soldiers and military equipment stored at military airports were thus transported to civil airports, where the civilian aircraft chartered by the military was boarded and loaded. This situation generated additional costs and complicated procedures for both civil airports and for the military.

The aim of this Amendment was thus to introduce laws that would make it possible for civil aircraft to perform air operations from Polish military airports, maintaining at the same time the necessary safety level. The Draft assumed also that the change should provide a level of operational safety equal to that ensured in the performance of flight operations by civil aircrafts at civilian airports.

In order to achieve this goal, the following solutions were introduced into the Polish Aviation Law Act:

1) the main condition for using military airport is the prior publication of technical and operational airport data in the Aeronautical Information Publication (hereafter, AIP Poland),

2) take-offs and landings are permitted for civilian helicopters and propellerdriven airplanes with a maximum take-off weight not exceeding $5700 \mathrm{~kg}$ or with a passenger seating configuration of less than 10, regardless of the nature of the operation,

3) take-offs and landings are permitted for civilian aircraft in order to carry out tasks fulfilling the needs of the Polish Armed Forces in relation to the transport of cargo,

4) take-offs and landings are permitted for civilian aircraft in order to carry out tasks fulfilling the needs of the Polish Armed Forces in relation to the transport of soldiers, officers of military intelligence and counterintelligence, Government Protection Bureau and army personnel. This rule is conditional upon the military airport in question meeting 
the technical and operational requirements of civilian airports for public use with so-called 'limited certification'. These are airports open for air traffic, which are not subject to the requirements of EU legislation in this area ${ }^{9}$.

Military air traffic control services will be provided in all of the above types of operations. This service should be provided in accordance with the requirements of EU legislation on air navigation services.

Interestingly, a special legal solution was introduced regarding civil liability for damages caused by the movement of civil aircrafts performing take-offs and landings in order to transport soldiers, officers of military intelligence and counterintelligence, Government Protection Bureau and army personnel.

General rules for civil liability to third parties for damages caused by aircrafts are as follows. Article 206(1) of the Aviation Law Act foresee that civil liability for damages caused by the movement of an aircraft is subject to the provisions of the Civil Code on traffic accidents caused by motor-vehicles. Nevertheless, no right to compensation arises if the damage results from the mere fact of the passage of an aircraft through the airspace in conformity with existing air traffic regulations (Article 206(2)). Moreover, the Aviation Law Act provides some additions to the provisions of the Civil Code. It is established in Article 207(1) that liability for compensation covered by Article 206 shall relate to the operator of the aircraft. The definition of the term 'operator' covers the person who was making use of the aircraft at the time when the damage occurred. However, if control of the navigation of the aircraft was retained by the person from whom the right to make use of the aircraft was derived, than that person shall be seen as the operator (Article 207(2)(3)). A person shall be considered to be making use of an aircraft when using it personally, or when the aircraft is used by his employees or agents in the course of their employment, whether or not within the scope of their authority (Article 207(4)). The registered owner of the aircraft shall be presumed to be the operator and shall be liable as such unless, in proceedings for the determination of his liability, he proves that some other person was the operator of the aircraft in question (Article 207(5)). If a person makes use of an aircraft without the consent of the person entitled to its navigational control, the latter, unless he proves that he has exercised due care to prevent such use, shall be jointly and severally liable with the unlawful user for the damage sustained (Article 207(6)). If any other person causes damage by his/her fault, the latter shall be jointly and severally liable with the persons specified in the Article 207 (Article 207(7)) (Konert, 2016; Konert, 2014a; Konert, 2014b).

\footnotetext{
${ }^{9}$ See Article 59a(6) of the Aviation Law Act.
} 
In addition to these rules, the new Amendment places special liability on the Polish State for accidents of civil aircrafts operating from, or to military airport when caring out tasks fulfilling the needs of the Polish Armed Forces in the transport of soldiers, officers of military intelligence and counterintelligence, Government Protection Bureau and army personnel. This creates additional joint and several liability of the State Treasury, represented by the organizational unit or the organizational union of the Armed Forces using the military airport (Article 207(8)) (Konert, 2016).

Since the legislature did not specify any special principles of liability here, it is accepted that the liability of the Treasury in such cases is absolute (objective liability). The only condition for such liability is to establish that the damage caused by the movement of the aircraft corresponds to one of the abovementioned entities referred to in Article 207(1)-(6), which corresponds to objective liability (risk-based liability), or other entity that is liable for fault.

Such a solution raises many questions and doubts. It is unknown how far the liability of the Treasury can reach - managing military airport - for damages resulting from an accident that occurred in connection with 'civilian flights' performed for the Armed Forces.

In particular, this applies to situations without a connection between the accident and an act or omission on the side of the airport managing body. For example, a problem would arise if an accident occurs even before precontact with the military air traffic control service, when the crew of the civil aircraft performing a flight for the Polish Armed Forces remain far from the military airport, in airspace where air navigation services are provided by civil institutions.

\section{Forthcoming amendment of the Aviation Law Act}

In 2015, the government started also a legislative process directed at a comprehensive amendment of the Aviation Law Act. The project involves adapting the Act to new or revised EU legislation. It also addresses passenger rights protection issues, air navigation, aviation personnel, aviation technology, aviation business and air transport, air operations, airports and civil aviation security. As part of the intergovernmental agreement, the Legislative Council made its comments ${ }^{10}$.

The legislative process continued recently when the current version of the Draft Amendment was sent for final approval of the government. It can

10 http://radalegislacyjna.gov.pl/dokumenty/opinia-z-3-lipca-2015-r-o-projekcie-ustawy-ozmianie-ustawy-prawo-lotnicze-oraz-niektorych. 
thus be assumed that this Draft should find itself on this year's parliamentary agenda. Importantly, the project has to adjust the provisions of the Act to new or revised EU legislation. Looking even only at aviation safety, at least a dozen acts of EU law have been issued since the last comprehensive amendment of the Polish Aviation Law. Furthermore, the goal of the forthcoming amendment is also to redesign those existing parts of the Aviation Law Act, which had proven to cause practical problems. For example, it has been proposed to limit administrative procedures for civil claims for canceled or delayed flights, or to create the institution of an Ombudsman for passengers in order to conduct mediation proceedings.

\section{References}

Konert, A. (2016). Komentarz do art. 207. In: M. Żylicz (red). Komentarz do ustawy Prawo lotnicze. Warszawa: Wolters Kluwer.

Konert, A. (2014a). New progress and challenges in the air law - air crash victims families protection, Warszawa: Wydawnictwo Uczelni Łazarskiego 2014.

Konert, A. (2014b). Odpowiedzialność za szkodę na ziemi wyrzadzona ruchem statku powietrznego. Warszawa: Wolters Kluwer. 